\title{
Biomarkers and Peak Oxygen Uptake in Patients with Chronic Lung Disease
}

\author{
Micha T. Maeder ${ }^{a, b}$ Martin H. Brutsche ${ }^{c}$ Nisha Arenja $^{d}$ Thenral Socrates $^{d}$ \\ Miriam Reiter $^{d} \quad$ Julia Meissner ${ }^{d}$ Daniel Staub ${ }^{d}$ Nils G. Morgenthaler ${ }^{e}$ \\ Andreas Bergmann ${ }^{\text {e }}$ Christian Mueller ${ }^{d}$ \\ ${ }^{a}$ Baker IDI Heart and Diabetes Institute, Melbourne, Vic., Australia; Divisions of ${ }^{b}$ Cardiology and ${ }^{c}$ Pneumology, \\ Kantonsspital, St. Gallen, and 'Department of Internal Medicine, University Hospital Basel, Basel, Switzerland; \\ e Department of Research, BRAHMS AG, Biotechnology Center, Hennigsdorf, Germany
}

\section{Key Words}

Biomarkers - Cardiopulmonary exercise testing •

Endothelin $\cdot$ Peak oxygen consumption

\begin{abstract}
Background: Peak oxygen uptake (peak $\mathrm{VO}_{2}$ ) is a predictor of outcome in patients with lung disease. In these patients, peak $\mathrm{VO}_{2}$ is typically determined by ventilation and gas exchange. However, it is not well known whether cardiac strain contributes to peak $\mathrm{VO}_{2}$ in patients with chronic lung disease. Objective: To assess the relationship between several novel biomarkers reflecting different aspects of cardiac function and peak $\mathrm{VO}_{2}$ in patients with chronic lung disease. Methods: Plasma concentrations of midregional pro-A-type natriuretic peptide (MR-proANP), midregional proadrenomedullin (MR-proADM), C-terminal proendothelin-1 (CT-proET-1), and C-terminal provasopressin (copeptin) were measured in 85 patients with a variety of chronic pulmonary diseases [age $57 \pm 14$ years, forced expiratory volume in the 1st second $\left(\mathrm{FEV}_{1}\right) 76 \pm 23 \%$ of the predicted value] undergoing maximal cardiopulmonary exercise testing (peak $\mathrm{VO}_{2} 18.6 \pm 6.6$ $\mathrm{ml} / \mathrm{kg} / \mathrm{min}$ ). Results: Raised MR-proANP ( $r=-0.54)$, MRproADM $(r=-0.54)$, and CT-proET-1 $(r=-0.49 ; p<0.001$ for all) but not copeptin $(r=-0.05 ; p=0.68)$ concentrations were
\end{abstract}

associated with lower peak $\mathrm{VO}_{2}$, and these associations were independent of age, gender, medication, $\mathrm{FEV}_{1}$ and oxygenation. The relationship between MR-proANP, MR-proADM, and $\mathrm{CT}$-proET-1 and peak $\mathrm{VO}_{2}$ was significant whether patients had an obstructive ventilatory disease or not. Conclusions: In patients with chronic lung disease, several biomarkers known to reflect measures of cardiac function were associated with peak $\mathrm{VO}_{2}$ independent of lung function, indicating that cardiac strain may contribute to exercise limitation in these patients due to concomitant cardiac disease or in the context of a pulmonary-cardiac interaction.

Copyright $\odot 2010$ S. Karger AG, Basel

\section{Introduction}

Cardiopulmonary exercise testing (CPET) is an established tool for risk stratification in patients with a variety of pulmonary diseases including chronic obstructive pulmonary disease (COPD), interstitial lung disease, pulmonary vascular disorders, and cystic fibrosis [1-3]. The prognostic power of peak oxygen uptake (peak $\mathrm{VO}_{2}$ ) in these patients is explained by the fact that peak $\mathrm{VO}_{2}$ is not only a measure of the degree of impairment of ventilation and gas exchange but also reflects nonpulmonary com-

\section{KARGER \\ Fax +4161306 1234 E-Mail karger@karger.ch} www.karger.com

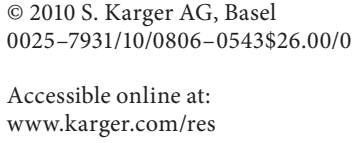

Micha T. Maeder, MD

Division of Cardiology, Kantonsspital St. Gallen

Rorschacherstrasse 95

CH-9007 St. Gallen (Switzerland)

Tel. +41 7149411 76, Fax +41 7149461 42,E-Mail micha.maeder@ kssg.ch 
ponents of exercise capacity, such as cardiac output and muscular adaptation to exercise, and thereby represents an integrative measurement of response to exercise. However, the contribution of cardiovascular factors to exercise limitation in patients with lung disease is not well documented. We have previously shown that in patients with chronic lung disease, B-type natriuretic peptide and $\mathrm{N}$-terminal-pro-B-type natriuretic peptide (NT-proBNP) were independent predictors of a peak $\mathrm{VO}_{2}<15 \mathrm{ml} / \mathrm{kg} /$ min [4], which is an established cut-off indicating an increased risk of perioperative complications in patients with lung disease being considered for lung cancer surgery who cannot be considered as low risk based on their forced expiratory volume in the 1st second $\left(\mathrm{FEV}_{1}\right)$ and diffusion capacity $[2,5-7]$. This seems to indicate that cardiac strain may significantly contribute to peak $\mathrm{VO}_{2}$ in patients with lung disease. In fact, recent studies suggested a close link between pulmonary and cardiac function in patients with lung disease $[8,9]$.

In patients with cardiac disease, several novel biomarkers, such as midregional pro-A-type natriuretic peptide (MR-proANP) [10-12], midregional proadrenomedullin (MR-proADM) [13], C-terminal proendothelin-1 (CT-proET-1) [14], and C-terminal provasopressin (CT-proAVP, copeptin) [15, 16], which are promising markers of pathophysiological processes, have been shown to be as accurate or even more accurate in predicting prognosis than the established B-type natriuretic peptides. MR-proANP is the stable midregional part of the ANP precursor peptide and is thereby considered to be a marker of left atrial stretch [17]. In patients with chronic heart failure (HF), MR-proANP is a marker of left-ventricular ejection fraction (LVEF) and mortality $[11,12]$, and in postmyocardial infarction (MI) patients, MR-proANP is a marker of outcome too [10]. MR-pro$\mathrm{ADM}$ is the midregional part of the precursor peptide of adrenomedullin, a peptide with vasorelaxing and natriuretic properties [18]. In HF patients, adrenomedullin is released from the myocardium [18] and is a prognostic marker [19]. CT-proET-1 is the C-terminal part of the precursor peptide of endothelin-1 (ET-1), an endothelium-derived vasoconstrictor contributing to heightened systemic [20] and pulmonary vascular tone [21]. CT-proET-1 is a prognostic marker in the post-MI setting [14]. Copeptin is the C-terminal fragment of the AVP precursor peptide and thereby reflects plasma osmolality but interestingly seems also to be a marker of the individual stress level [22]. Copeptin has been shown to be an early marker of acute MI and a marker of left-ventricular remodeling and dysfunction in the post-MI setting [23].
In addition, copeptin provides prognostic information in patients post-MI [23] and those with chronic HF [15]. The advantage of these four novel markers over measurement of the biologically active substances lies in the fact that prohormones have a longer half-life and thereby represent more reliable analytes.

Accordingly, the aim of the present study was to assess the relationship between MR-proANP, MR-proADM, CT-proET-1, and copeptin and peak $\mathrm{VO}_{2}$ in patients with chronic lung disease. We hypothesized that raised concentrations of these markers were associated with lower peak $\mathrm{VO}_{2}$.

\section{Methods}

Study Design

One-hundred and four consecutive patients with chronic lung disease referred for CPET for the evaluation of exercise capacity were eligible. There were no a priori exclusion criteria. Nineteen patients not fulfilling criteria for appropriate effort (see below) were secondarily excluded, leaving 85 patients for the present analysis. The study population represents a subgroup of a population on which we have reported previously [24]. All patients underwent CPET including spirometry and blood gases as well as biomarker measurement in a prospective manner. Information on cardiac function was obtained from previously performed echocardiograms. The study was approved by the Ethics Committee of Basel. Written informed consent was obtained from all participating patients.

\section{CPET Procedures}

Spirometry for measurement of $\mathrm{FEV}_{1}$ and forced vital capacity (FVC) was performed immediately before CPET. Thereafter, patients underwent symptom-limited upright cycle exercise tests (Jaeger, Würzburg, Germany) using ramp protocols with continuous monitoring of the electrocardiogram and noninvasive blood pressure measurement every second minute. Standard criteria for test termination were applied [25]. Minute ventilation (VE), $\mathrm{VO}_{2}$, and carbon dioxide output $\left(\mathrm{VCO}_{2}\right)$ were obtained breath by breath and averaged at 30-second intervals (SensorMedics Yorba Linda, Calif., USA). Peak $\mathrm{VO}_{2}$ was expressed as the highest 10 -second average values obtained during the last $30 \mathrm{~s}$ of the test. Peak $\mathrm{VO}_{2}$ was expressed as body weight-indexed data as well as \%predicted peak $\mathrm{VO}_{2}$. Oxygen pulse was calculated as peak $\mathrm{VO}_{2}$ divided by peak heart rate. Ventilatory efficiency was expressed as the peak $\mathrm{VE} / \mathrm{VCO}_{2}$ ratio, which, similarly to the $\mathrm{VE} / \mathrm{VCO}_{2}$ slope, is a strong predictor of outcome in patients with HF [26]. Arterial blood was obtained at rest and peak exercise (i.e. immediately after cessation of exercise) from a radial or brachial artery and analyzed immediately. Maximal or near-maximal effort was assumed if at least one of the following criteria was fulfilled: (1) peak heart rate $>80 \%$ predicted; (2) respiratory exchange ratio $>1.2$; (3) lactate at peak exercise (measured in arterial blood with a blood gas analyzer) $>4.0 \mathrm{mmol} / \mathrm{l}$, or (4) difference between base excess at rest and peak exercise $\leq 2.5 \mathrm{mmol} / \mathrm{l}[27]$. 
Table 1. Baseline characteristics of the entire study population and of patients with an $\mathrm{FEV}_{1} / \mathrm{FVC}$ ratio $<0.7$ versus $\geq 0.7$

\begin{tabular}{|c|c|c|c|c|}
\hline & $\begin{array}{l}\text { All } \\
(n=85)\end{array}$ & $\begin{array}{l}\mathrm{FEV}_{1} / \mathrm{FVC} \\
<0.7(\mathrm{n}=40)\end{array}$ & $\begin{array}{l}\mathrm{FEV}_{1} / \mathrm{FVC} \\
\geq 0.7(\mathrm{n}=45)\end{array}$ & $\mathrm{p}$ value \\
\hline Age, years & $57 \pm 14$ & $59 \pm 14$ & $55 \pm 15$ & 0.17 \\
\hline Male gender & $50(59 \%)$ & $18(45 \%)$ & $32(71 \%)$ & 0.02 \\
\hline Body mass index, $\mathrm{kg} / \mathrm{m}^{2}$ & $26.0 \pm 4.7$ & $25.4 \pm 4.5$ & $26.6 \pm 4.9$ & 0.24 \\
\hline COPD & $39(46 \%)$ & $26(65 \%)$ & $13(29 \%)$ & 0.001 \\
\hline Bronchial asthma & $13(15 \%)$ & $5(13 \%)$ & $8(18 \%)$ & 0.50 \\
\hline Other lung disease $^{1}$ & $33(39 \%)$ & $9(23 \%)$ & $24(53 \%)$ & 0.004 \\
\hline Lung cancer & $33(39 \%)$ & $21(53 \%)$ & $12(27 \%)$ & 0.02 \\
\hline \multicolumn{5}{|l|}{ Other medical history } \\
\hline Coronary artery disease & $15(18 \%)$ & $8(20 \%)$ & $7(16 \%)$ & 0.59 \\
\hline Previous myocardial infarction & $10(12 \%)$ & $6(15 \%)$ & $4(9 \%)$ & 0.38 \\
\hline Other heart disease & $8(9 \%)$ & $3(8 \%)$ & $5(11 \%)$ & 0.65 \\
\hline Diabetes mellitus & $7(8 \%)$ & $3(8 \%)$ & $4(9 \%)$ & 0.82 \\
\hline Current smoking & $25(29 \%)$ & $16(40 \%)$ & $9(20 \%)$ & 0.04 \\
\hline Previous smoking & $40(47 \%)$ & $15(38 \%)$ & $25(56 \%)$ & 0.10 \\
\hline \multicolumn{5}{|l|}{ Medication } \\
\hline Inhaled corticosteroids & $28(33 \%)$ & $18(45 \%)$ & $10(22 \%)$ & 0.03 \\
\hline Inhaled $\beta_{2}$-mimetics & $33(39 \%)$ & $21(53 \%)$ & $12(27 \%)$ & 0.02 \\
\hline$\beta$-Blockers & $16(19 \%)$ & $6(15 \%)$ & $10(22 \%)$ & 0.40 \\
\hline ACEI/ARB & $15(18 \%)$ & $9(23 \%)$ & $6(13 \%)$ & 0.27 \\
\hline Diuretic & $13(15 \%)$ & $4(10 \%)$ & $9(20 \%)$ & 0.01 \\
\hline Aspirin & $15(18 \%)$ & $7(18 \%)$ & $8(18 \%)$ & 0.97 \\
\hline Statin & $19(22 \%)$ & $8(20 \%)$ & $11(24 \%)$ & 0.62 \\
\hline
\end{tabular}

Data are given as numbers and percentages or means $\pm \mathrm{SD} . \mathrm{ACEI} / \mathrm{ARB}=$ Angiotensin-converting enzyme inhibitor or angiotensin receptor blocker. ${ }^{1}$ For details, see text.

\begin{abstract}
Biomarker Measurement
A specimen of venous blood was drawn from an antecubital vein immediately before the test in the seated position. Samples were collected in plastic tubes containing ethylenediaminetetraacetatic acid (EDTA), placed on ice, centrifuged at 3,000 g, and stored at $-80^{\circ} \mathrm{C}$. Plasma samples were analyzed approximately 1 year after collection by laboratory technicians blinded to patient characteristics and CPET results. Biomarkers were measured using novel assays which have been described in detail elsewhere [28-31]. MRproANP was measured using the BRAHMS MR-proANP LIA [28], MR-proADM was measured using the BRAHMS MR-proADM LIA [29], CT-proET-1 was measured using the BRAHMS CT-proET-1 LIA [30], and copeptin was measured using the BRAHMS CT-proAVP LIA [31] (all assays from BRAHMS AG, Hennigsdorf, Germany). The stability at $-20^{\circ} \mathrm{C}$ during 6 months has been demonstrated for MR-proANP [28], MR-proADM [29], and CT-proET-1 [30]. Similar data demonstrating the stability of copeptin during long-term storage are not available. However, the excellent stability of copeptin in EDTA plasma at room temperature has been demonstrated previously. After 14 days at room temperature in EDTA plasma, the mean measured value was still $97.6 \%$ of the initial value measured in EDTA plasma. After 4 cycles of freezing and thawing the mean measured value was $102 \%$ of the original value [31]. Based on these data, we think that it can be extrapolated that long-term storage at $-80^{\circ} \mathrm{C}$ is a suitable storage method.
\end{abstract}

\section{Statistical Analysis}

Data were expressed as counts and percentages, means \pm standard deviation (SD), and median (interquartile range). We compared patients with an $\mathrm{FEV}_{1} / \mathrm{FVC}$ ratio $<0.70$ as measured under therapy on the day of the test (i.e. patients with irreversible obstruction) and patients with an $\mathrm{FEV}_{1} / \mathrm{FVC}$ ratio $>0.70$ using the $\chi^{2}$ test, unpaired t test, or Mann-Whitney $U$ test. The rationale for this approach is based on the observation that the degree of airflow obstruction is related to cardiac output [8], and that we wanted to assess whether our results apply for patients with obstructive and nonobstructive pathology. Correlations between parameters of interest were performed using Spearman correlation coefficients. Multivariable linear regression with body weight-indexed peak $\mathrm{VO}_{2}$ and \%predicted $\mathrm{VO}_{2}$ as dependent variables was performed with all available information and measurements at rest (tables 1,2$)$ as covariates (ln-transformation in case of a skewed distribution). We performed direct as well as backward and forward models for each of the four biomarkers. In addition, an analysis with peak $\mathrm{VO}_{2}$ as a categorical variable was performed using the previously published cut-off of $15 \mathrm{ml} / \mathrm{kg} / \mathrm{min}$ [5-7]. Receiver operator characteristics (ROC) curves were constructed to illustrate the ability of the biomarkers to reflect a peak $\mathrm{VO}_{2}<15 \mathrm{ml} /$ $\mathrm{kg} / \mathrm{min}$. Areas under the ROC curves (AUC) were compared using the method of DeLong et al. [32]. Multivariable logistic regression was then performed to identify independent predictors of a 
Table 2. Measurements at rest in the entire study population and in patients with an $\mathrm{FEV}_{1} / \mathrm{FVC}$ ratio $<0.7$ versus $\geq 0.7$

\begin{tabular}{|c|c|c|c|c|}
\hline & $\begin{array}{l}\text { All } \\
(\mathrm{n}=85)\end{array}$ & $\begin{array}{l}\mathrm{FEV}_{1} / \mathrm{FVC} \\
<0.7(\mathrm{n}=40)\end{array}$ & $\begin{array}{l}\mathrm{FEV}_{1} / \mathrm{FVC} \\
\geq 0.7(\mathrm{n}=45)\end{array}$ & $\mathrm{p}$ value \\
\hline Heart rate, bpm & $83 \pm 15$ & $83 \pm 16$ & $83 \pm 14$ & 0.72 \\
\hline Systolic blood pressure, $\mathrm{mm} \mathrm{Hg}$ & $127 \pm 19$ & $127 \pm 17$ & $127 \pm 20$ & 0.98 \\
\hline Diastolic blood pressure, $\mathrm{mm} \mathrm{Hg}$ & $86 \pm 12$ & $82 \pm 13$ & $89 \pm 10$ & 0.02 \\
\hline Creatinine clearance, $\mathrm{ml} / \mathrm{min}$ & $94 \pm 33$ & $93 \pm 34$ & $96 \pm 32$ & 0.70 \\
\hline LVEF, \% & $60(55-65) n=40$ & $60(52-65) n=18$ & $60(60-65) n=22$ & 0.18 \\
\hline Respiratory rate, $\min ^{-1}$ & $19 \pm 6$ & $20 \pm 6$ & $19 \pm 6$ & 0.42 \\
\hline FVC, 1 & $3.22 \pm 1.00$ & $2.95 \pm 0.96$ & $3.46 \pm 0.98$ & 0.02 \\
\hline \%predicted FVC, \% & $92 \pm 20$ & $92 \pm 19$ & $92 \pm 22$ & 0.96 \\
\hline $\mathrm{FEV}_{1}, 1$ & $2.19 \pm 0.84$ & $1.70 \pm 0.64$ & $2.62 \pm 0.77$ & $<0.001$ \\
\hline$\%$ predicted $\mathrm{FEV}_{1}, \%$ & $76 \pm 23$ & $65 \pm 18$ & $85 \pm 22$ & $<0.001$ \\
\hline $\mathrm{FEV}_{1} / \mathrm{FVC}$ & $0.67 \pm 0.12$ & $0.58 \pm 0.09$ & $0.76 \pm 0.07$ & $<0.001$ \\
\hline Hemoglobin, g/dl & $14.2 \pm 2.0$ & $13.6 \pm 1.9$ & $14.6 \pm 1.9$ & 0.01 \\
\hline $\mathrm{PaO}_{2}, \mathrm{~mm} \mathrm{Hg}$ & $80 \pm 13$ & $75 \pm 11$ & $84 \pm 14$ & 0.003 \\
\hline $\mathrm{SaO}_{2}, \%$ & $95(93-96)$ & $94(91-96)$ & $95(93-96)$ & 0.03 \\
\hline $\mathrm{PaCO}_{2}, \mathrm{~mm} \mathrm{Hg}$ & $35 \pm 5$ & $36 \pm 4$ & $34 \pm 5$ & 0.16 \\
\hline $\mathrm{D}(\mathrm{A}-\mathrm{a}) \mathrm{O}_{2}, \mathrm{~mm} \mathrm{Hg}$ & $25 \pm 14$ & $30 \pm 13$ & $21 \pm 13$ & 0.006 \\
\hline
\end{tabular}

Data are given as means $\pm \mathrm{SD}$ or medians (interquartile range in parentheses). $\mathrm{SaO}_{2}=$ Arterial oxygen saturation; $\mathrm{D}(\mathrm{A}-\mathrm{a}) \mathrm{O}_{2}=$ alveolo-arterial oxygen pressure difference.

peak $\mathrm{VO}_{2}<15 \mathrm{ml} / \mathrm{kg} / \mathrm{min}$. All parameters available before the exercise test (tables 1, 2; first model) as well as biomarkers (additional models) were tested. $\mathrm{p}<0.05$ was considered statistically significant. Analysis was performed using commercially available software packages (SPSS/PC, version 15.0, SPSS Inc., Chicago, Ill., USA, and Analyse-it V2.04, Leeds, UK).

\section{Results}

\section{Patient Characteristics}

We studied 85 patients with the following primary diagnoses: 39 (46\%) had COPD, 13 (15\%) had asthma and 33 (39\%) had other lung diseases, including sarcoidosis $(\mathrm{n}=3)$, pulmonary arterial hypertension $(\mathrm{n}=2)$, interstitial lung disease $(n=6)$, alveolitis $(n=1)$, bronchiectasis $(\mathrm{n}=2)$, unclear lung diseases $(\mathrm{n}=2)$, or lung cancer/mesothelioma $(\mathrm{n}=17)$. Fifteen patients also had lung cancer along with another pulmonary disease. The characteristics of the entire study group are presented in table 1.

\section{Measurements at Rest and Responses to Exercise}

Measurements at rest and responses to exercise are shown in tables 2 and 3. As expected, we studied a population with overall clearly abnormal lung function and impaired functional capacity as indicated by a mean \%predicted peak $\mathrm{VO}_{2}$ of $71 \%$. Forty (47\%) patients had an obstructive ventilator defect on the day of CPET.

\section{Biomarker Concentrations}

The median MR-proANP, MR-proADM, CT-proET-1, and copeptin concentrations and interquartile ranges are presented in table 4 . As shown in table 5 , there were significant correlations between the biomarkers, with $\mathrm{r}^{2}$ values ranging from to 0.06 to 0.48 .

\section{Relationship between Biomarkers and Peak $\mathrm{VO}_{2}$}

There were moderate inverse correlations between peak $\mathrm{VO}_{2}$ and MR-proANP, MR-proADM and CTproET-1 ( $<<0.001$ for all) but not copeptin (fig. 1). In all multivariable linear regression models, lower MR-proANP $(\beta=-0.32 ; p<0.001)$ was an independent predictor of a higher peak $\mathrm{VO}_{2}$. Higher $\mathrm{FEV}_{1}$, higher arterial oxygen pressure $\left(\mathrm{PaO}_{2}\right)$, higher arterial carbon dioxide pressure $\left(\mathrm{PaCO}_{2}\right)$, and lower body mass index (BMI) were additional independent predictors of higher peak $\mathrm{VO}_{2}$. In some models (forward models), lower MR-proADM ( $\beta=$ -0.32; $\mathrm{p}<0.001$ ) along with higher $\mathrm{FEV}_{1}$, higher $\mathrm{PaO}_{2}$, higher $\mathrm{PaCO}_{2}$, and lower BMI, and lower CT-proET-1 $(\beta=-0.29 ; p=0.001)$ along with higher $F V_{1}$, higher 
Table 3. Measurements at peak exercise in the entire study population and in patients with an $\mathrm{FEV}_{1} / \mathrm{FVC}$ ratio $<0.7$ versus $\geq 0.7$

\begin{tabular}{|c|c|c|c|c|}
\hline & $\begin{array}{l}\text { All } \\
(n=85)\end{array}$ & $\begin{array}{l}\mathrm{FEV}_{1} / \mathrm{FVC} \\
<0.7(\mathrm{n}=40)\end{array}$ & $\begin{array}{l}\mathrm{FEV}_{1} / \mathrm{FVC} \\
\geq 0.7(\mathrm{n}=45)\end{array}$ & $\mathrm{p}$ value \\
\hline Duration of exercise, min & $6.0(4.8-7.0)$ & $5.0(4.2-6.0)$ & $6.6(5.7-8.0)$ & $<0.001$ \\
\hline Peak heart rate, bpm & $139 \pm 25$ & $137 \pm 24$ & $140 \pm 26$ & 0.48 \\
\hline Predicted heart rate, $\%$ & $85 \pm 14$ & $84 \pm 13$ & $85 \pm 14$ & 0.93 \\
\hline Systolic blood pressure, mm Hg & $183 \pm 31$ & $188 \pm 33$ & $179 \pm 29$ & 0.20 \\
\hline Diastolic blood pressure, $\mathrm{mm} \mathrm{Hg}$ & $92 \pm 16$ & $92 \pm 18$ & $92 \pm 14$ & 0.96 \\
\hline Respiratory rate, $\mathrm{min}^{-1}$ & $35 \pm 8$ & $33 \pm 7$ & $37 \pm 9$ & 0.04 \\
\hline Peak work rate, $\mathrm{W} / \mathrm{kg}$ & $1.62 \pm 0.65$ & $1.47 \pm 0.54$ & $1.76 \pm 0.71$ & 0.04 \\
\hline Peak $\mathrm{VO}_{2}, 1 / \mathrm{min}$ & $1.38 \pm 0.58$ & $1.24 \pm 0.57$ & $1.50 \pm 0.57$ & 0.04 \\
\hline Peak $\mathrm{VO}_{2}, \mathrm{ml} / \mathrm{kg} / \mathrm{min}$ & $18.6 \pm 6.6$ & $17.5 \pm 6.2$ & $19.6 \pm 6.9$ & 0.14 \\
\hline Predicted peak $\mathrm{VO}_{2}, \%$ & $71 \pm 19$ & $71 \pm 17$ & $70 \pm 21$ & 0.86 \\
\hline$\Delta \mathrm{VO}_{2} / \Delta$ work rate, $\mathrm{ml} / \mathrm{W} / \mathrm{min}$ & $9.4 \pm 1.9$ & $9.4 \pm 1.5$ & $9.3 \pm 2.1$ & 0.69 \\
\hline Peak oxygen pulse, ml/beat & $9.8 \pm 3.4$ & $8.9 \pm 3.2$ & $10.7 \pm 3.4$ & 0.01 \\
\hline Respiratory exchange ratio & $1.18 \pm 0.14$ & $1.15 \pm 0.14$ & $1.20 \pm 0.14$ & 0.08 \\
\hline $\mathrm{VE}, 1 / \mathrm{min}$ & $60 \pm 23$ & $51 \pm 19$ & $69 \pm 23$ & $<0.001$ \\
\hline Peak VE/ $\mathrm{VCO}_{2}$ & $39.0 \pm 9.9$ & $37.9 \pm 8.4$ & $39.9 \pm 11.1$ & 0.35 \\
\hline $\mathrm{PaO}_{2}, \mathrm{~mm} \mathrm{Hg}$ & $86 \pm 21$ & $80 \pm 20$ & $92 \pm 22$ & 0.008 \\
\hline $\mathrm{SaO}_{2}, \%$ & $95(91-96)$ & $93(90-95)$ & $95(93-96)$ & 0.07 \\
\hline $\mathrm{PaCO}_{2}, \mathrm{~mm} \mathrm{Hg}$ & $35 \pm 6$ & $38 \pm 5$ & $33 \pm 5$ & 0.001 \\
\hline $\mathrm{D}(\mathrm{A}-\mathrm{a}) \mathrm{O}_{2}, \mathrm{~mm} \mathrm{Hg}$ & $29 \pm 19$ & $32 \pm 17$ & $26 \pm 21$ & 0.18 \\
\hline $\mathrm{pH}$ & $7.36(7.33-7.39)$ & $7.37(7.33-7.39)$ & $7.36(7.32-7.40)$ & 0.90 \\
\hline Lactate, $\mathrm{mmol} / \mathrm{l}$ & $5.8(4.4-7.7)$ & $5.8(4.2-7.1)$ & $5.9(4.4-8.5)$ & 0.25 \\
\hline
\end{tabular}

Data are given as means $\pm \mathrm{SD}$ or medians (interquartile range in parentheses). $\mathrm{SaO}_{2}=$ Arterial oxygen saturation; $\mathrm{D}(\mathrm{A}-\mathrm{a}) \mathrm{O}_{2}=$ alveolo-arterial oxygen pressure difference.

Table 4. Biomarkers in the entire study population and of patients with an $\mathrm{FEV}_{1} / \mathrm{FVC}$ ratio $<0.7$ versus $\geq 0.7$

\begin{tabular}{lllll}
\hline & $\begin{array}{l}\text { All } \\
(\mathrm{n}=85)\end{array}$ & $\begin{array}{l}\mathrm{FEV}_{1} / \mathrm{FVC}<0.7 \\
(\mathrm{n}=40)\end{array}$ & $\begin{array}{l}\mathrm{FEV}_{1} / \mathrm{FVC} \geq 0.7 \\
(\mathrm{n}=45)\end{array}$ & p value \\
\hline MR-proANP, pmol/1 & $62.5(40.0-97.7)$ & $72.9(43.3-112.5)$ & $57.7(37.0-84.0)$ & 0.10 \\
MR-proADM, nmol/1 & $0.57(0.46-0.76)$ & $0.62(0.46-0.78)$ & $0.54(0.47-0.75)$ & 0.38 \\
CT-proET-1, pmol/1 & $68.0(53.6-88.2)$ & $66.1(54.2-88.5)$ & $68.9(52.6-88.2)$ & 0.96 \\
CT-proAVP, pmol/1 & $6.5(4.8-10.2)$ & $5.78(4.17-8.31)$ & $7.49(5.11-12.0)$ & 0.03 \\
\hline
\end{tabular}

Data are given as medians (interquartile range in parentheses).

Table 5. Correlations between biomarkers

\begin{tabular}{lllll}
\hline & MR-proANP & MR-proADM & CT-proET-1 & CT-proAVP \\
\hline MR-proANP & - & $\mathrm{r}=0.69 ; \mathrm{p}<0.001$ & $\mathrm{r}=0.55 ; \mathrm{p}<0.001$ & $\mathrm{r}=0.25 ; \mathrm{p}=0.02$ \\
MR-proADM & $\mathrm{r}=0.69 ; \mathrm{p}<0.001$ & - & $\mathrm{r}=0.72 ; \mathrm{p}<0.001$ & $\mathrm{r}=0.43 ; \mathrm{p}<0.001$ \\
CT-proET-1 & $\mathrm{r}=0.55 ; \mathrm{p}<0.001$ & $\mathrm{r}=0.72 ; \mathrm{p}<0.001$ & - & $\mathrm{r}=0.26 ; \mathrm{p}=0.02$ \\
CT-proAVP & $\mathrm{r}=0.25 ; \mathrm{p}=0.02$ & $\mathrm{r}=0.43 ; \mathrm{p}<0.001$ & $\mathrm{r}=0.26 ; \mathrm{p}=0.02$ & -
\end{tabular}

Spearman correlation coefficients are given. 


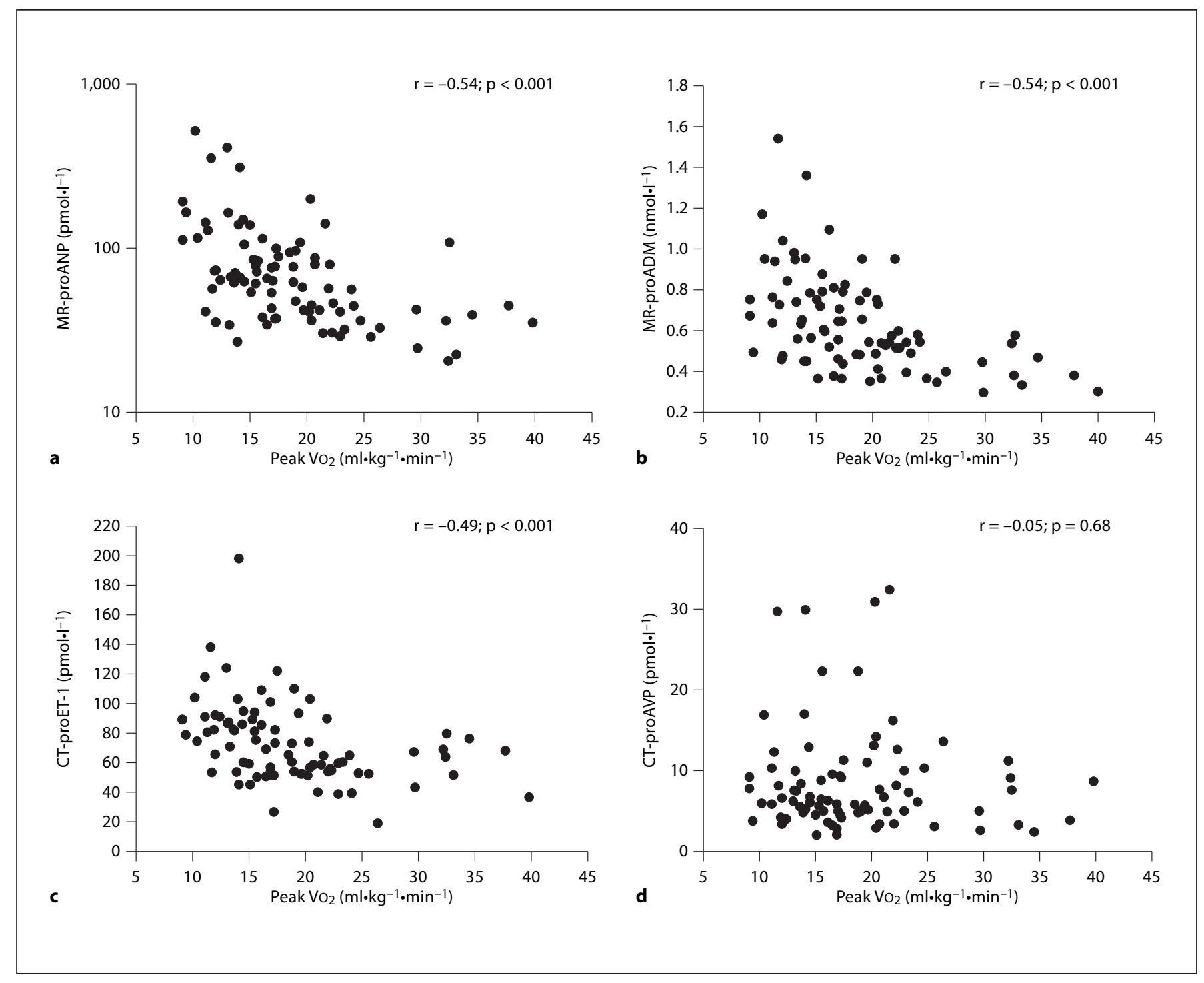

Fig. 1. Scatter plots showing the correlations between MR-proANP (a), MR-proADM (b), CT-proET-1 (c) and CT-proAVP (d) and peak $\mathrm{VO}_{2}$. Spearman correlation coefficients are given. Note the logarithmic scale for MRproANP.

$\mathrm{PaO}_{2}$, and lower $\mathrm{BMI}$ were also independently associated with higher peak $\mathrm{VO}_{2}$.

If peak $\mathrm{VO}_{2}$ was expressed as \%predicted value, it was significantly and inversely related to MR-proADM ( $\mathrm{r}=$ $-0.25 ; \mathrm{p}=0.02)$ and CT-proET-1 $(\mathrm{r}=-0.27 ; \mathrm{p}=0.01)$ but not MR-proANP $(\mathrm{r}=-0.19 ; \mathrm{p}=0.09)$ and copeptin $(\mathrm{r}=$ $-0.13 ; \mathrm{p}=0.22$ ). After multivariable adjustment, the associations between MR-proADM and CT-proET-1 and \%predicted peak $\mathrm{VO}_{2}$ were no longer significant, however (data no shown).

\section{Biomarkers for the Prediction of a Peak}

\section{$\mathrm{VO}_{2}<15 \mathrm{ml} / \mathrm{min} / \mathrm{kg}$}

When using peak $\mathrm{VO}_{2}$ as a categorical variable, MRproANP [105.0 (52.5-164.0) vs. $50.4(36.9-79.4) \mathrm{pmol} / \mathrm{l}]$, MR-proADM $[0.74 \quad(0.56-0.95)$ vs. $0.54 \quad(0.41-0.71)$ $\mathrm{nmol} / \mathrm{l}]$, CT-proET-1 [86.6 (74.4-104.9) vs. 59.4 (52.1$75.5) \mathrm{pmol} / \mathrm{l}](\mathrm{p}<0.001$ for all $)$ but not copeptin [7.5 (5.6$10.3)$ vs. $6.0(4.4-10.1) \mathrm{pmol} / \mathrm{l} ; \mathrm{p}=0.21]$ concentrations were significantly raised in patients with peak $\mathrm{VO}_{2}<15$ $\mathrm{ml} / \mathrm{kg} / \mathrm{min}$ as compared to those with peak $\mathrm{VO}_{2} \geq 15 \mathrm{ml} /$ $\mathrm{kg} / \mathrm{min}$. As shown in figure 2, the AUC for MR-proANP, 
MR-proADM, and CT-proET-1 for the prediction of a peak $\mathrm{VO}_{2}<15 \mathrm{ml} / \mathrm{kg} / \mathrm{min}$ were $0.74,0.74$, and $0.78(\mathrm{p}>0.4$ for all comparisons between the AUC).

Multivariable logistic regression (separate models for each marker) revealed higher MR-proANP, higher MRproADM, and higher CT-proET-1 as independent predictors of a peak $\mathrm{VO}_{2}<15 \mathrm{ml} / \mathrm{kg} / \mathrm{min}$. Other independent predictors of a peak $\mathrm{VO}_{2}<15 \mathrm{ml} / \mathrm{kg} / \mathrm{min}$ included lower $\mathrm{FEV}_{1}$, the presence of diabetes, and aspirin use (data not shown). In a model with all three biomarkers, only CTproET-1 remained independently predictive of peak $\mathrm{VO}_{2}$ $<15 \mathrm{ml} / \mathrm{kg} / \mathrm{min}$.

Relationship between Biomarkers and Oxygen Pulse and Ventilatory Efficiency

There were significant inverse correlations between MR-proANP ( $\mathrm{r}=-0.31 ; \mathrm{p}=0.004)$, MR-proADM $(\mathrm{r}=$ $-0.23 ; \mathrm{p}=0.03)$, and CT-proET-1 $(\mathrm{r}=-0.30 ; \mathrm{p}=0.005)$ and peak exercise oxygen pulse. In contrast, there was a trend towards a direct association between copeptin and oxygen pulse $(r=0.21 ; p=0.06)$. In addition, there were direct correlations between MR-proANP $(\mathrm{r}=0.32 ; \mathrm{p}=$ 0.003), MR-proADM ( $\mathrm{r}=0.29 ; \mathrm{p}=0.007)$, and CTproET-1 $(\mathrm{r}=0.30 ; \mathrm{p}=0.005)$ but not copeptin $(\mathrm{r}=0.09$; $\mathrm{p}=0.4)$ and the peak exercise $\mathrm{VE} / \mathrm{VCO}_{2}$ ratio.

\section{Comparison of Patients with $F E V_{1} / F V C<0.7$ versus $\geq 0.7$}

As shown in tables $1-3$, patients with $\mathrm{FEV}_{1} / \mathrm{FVC}<0.7$ $(\mathrm{n}=40)$ and those with $\mathrm{FEV}_{1} / \mathrm{FVC} \geq 0.7(\mathrm{n}=45)$ differed considerably with respect to gender, history, medication, lung function and blood gases at rest, and exercise responses. However, \%predicted peak $\mathrm{VO}_{2}$ was very similar between groups. Whilst there were no significant differences in MR-proANP, MR-proADM, and CT-proET-1 between the groups, copeptin was significantly lower in patients with $\mathrm{FEV}_{1} / \mathrm{FVC}<0.7$ compared to those with $\mathrm{FEV}_{1} /$ FVC $\geq 0.7$ (table 4). The inverse relationship between raised MR-proANP $\left(\mathrm{FEV}_{1} / \mathrm{FVC}<0.7: \mathrm{r}=-0.42 ; \mathrm{FEV}_{1} /\right.$ FVC $\geq 0.7: \mathrm{r}=-0.38)$, MR-proADM $(\mathrm{r}=-0.52 ; \mathrm{r}=-0.51)$, and CT-proET-1 $(\mathrm{r}=-0.42 ; \mathrm{r}=-0.42)$ with peak $\mathrm{VO}_{2}$ was present in both patients with $\mathrm{FEV}_{1} / \mathrm{FVC}<0.7$ and those with $\mathrm{FEV}_{1} / \mathrm{FVC} \geq 0.7$ ( $\mathrm{p}<0.05$ for all correlations).

\section{Subgroup Analyses}

In patients with available information on LVEF ( $\mathrm{n}=$ 40), we observed similar inverse correlations between MR-proANP ( $\mathrm{r}=-0.52 ; \mathrm{p}=0.001), \mathrm{MR}-\operatorname{proADM}(\mathrm{r}=$ $-0.46 ; \mathrm{p}=0.003)$, and CT-proET-1 $(\mathrm{r}=-0.53 ; \mathrm{p}<0.001)$ and peak $\mathrm{VO}_{2}$ as in the study population as a whole. There

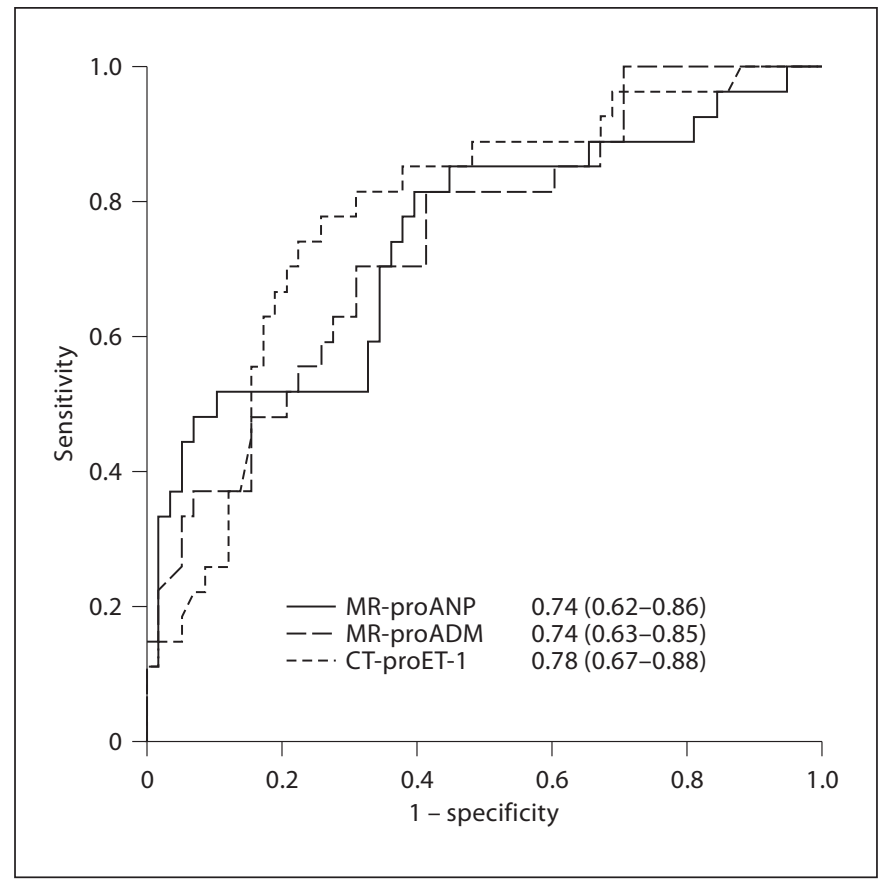

Fig. 2. ROC curves showing the accuracy of MR-proANP, MRproADM and CT-proET-1 in predicting a peak $\mathrm{VO}_{2}<15 \mathrm{ml} / \mathrm{kg} /$ min. AUC and 95\% confidence intervals are given.

was also a significant but weaker correlation between LVEF and peak $\mathrm{VO}_{2}(\mathrm{r}=0.32 ; \mathrm{p}=0.047)$ whereas there was no significant correlation between LVEF and biomarkers (data not shown). All correlations between the three biomarkers and peak $\mathrm{VO}_{2}$ remained statistically significant after adjustment for LVEF.

If the analysis was restricted to patients with $\mathrm{BMI}<30$ $\mathrm{kg} / \mathrm{m}^{2}(\mathrm{n}=69)$, MR-proANP $(\mathrm{r}=-0.52)$, MR-proADM $(\mathrm{r}=-0.53)$, and CT-proET-1 $(\mathrm{r}=-0.50 ; \mathrm{p}<0.001$ for all $)$ but not copeptin $(r=0.04 ; \mathrm{p}=0.8)$ were inversely associated with peak $\mathrm{VO}_{2}$. In those with $\mathrm{BMI} \geq 30 \mathrm{~kg} / \mathrm{m}^{2}(\mathrm{n}=$ 16), these correlations were even stronger (MR-proANP: $r=-0.74$, MR-proADM: $r=-0.61$, CT-proET-1: $r=-0.62$; $\mathrm{p}<0.05$ for all).

\section{Discussion}

The present study evaluating the association between biomarkers previously assessed in patients with cardiovascular disease and peak $\mathrm{VO}_{2}$ in patients with chronic lung disease revealed that raised MR-proANP, MRproADM, and CT-proET-1 were associated with lower 
peak $\mathrm{VO}_{2}$ independent of lung function, blood gases and medication.

Given that MR-proANP, MR-proADM and CTproET-1 provided information on peak $\mathrm{VO}_{2}$ independent of $\mathrm{FEV}_{1}$, they may reflect the cardiac output factor in peak $\mathrm{VO}_{2}$ equation. Similarly to NT-proBNP $[33,34]$, these biomarkers may be surrogates for coexisting leftsided cardiac dysfunction and thus exercise-induced postcapillary pulmonary hypertension. In fact, we found a weak inverse correlation between MR-proANP, MRproADM and CT-proET-1, and peak exercise oxygen pulse, potentially indicating a relationship with left-ventricular stroke volume during exercise, although this remains speculative given that oxygen pulse is not only determined by stroke volume but also the arteriovenous oxygen extraction, which we did not measure. In HF patients, an association between ET-1 and peak $\mathrm{VO}_{2}$ has been described previously [35]. In the subgroup with available data on LVEF, MR-proANP, MR-proADM and CT-proET-1 were significantly and inversely related to peak $\mathrm{VO}_{2}$ after adjustment for $\mathrm{LVEF}$, suggesting that these markers may provide composite information on cardiovascular strain beyond LVEF.

In addition, there seems to be an interaction between pulmonary and cardiac function $[9,36]$, per se associated with an impaired exercise capacity [9]. Patients with COPD and hyperinflation have been shown to have a lower peak $\mathrm{VO}_{2}$ and lower oxygen pulse than patients without hyperinflation [9], potentially suggesting a lower stroke volume in those with hyperinflation [9]. Possible mechanisms leading to a decreased left-ventricular stroke volume and thus peak $\mathrm{VO}_{2}$ in patients with both COPD and other lung diseases include exercise-induced precapillary pulmonary hypertension due to decreased pulmonary vascular bed and increased vasoreactivity [37], leftventricular diastolic dysfunction due to left-to-right ventricular interaction in the presence of pulmonary hypertension [38] as well as decreased venous return due to increased intrathoracic pressures [36]. Again, these speculations are limited by the fact that the value of oxygen pulse as a measure of stroke volume in patients with lung disease remains unclear [3]. However, in a recent population-based study, a greater extent of emphysema and more severe airflow obstruction were linearly related to impaired left-ventricular filling and lower stroke volume as assessed by cardiac magnetic resonance imaging [8]. Thus, although the underlying mechanisms are not fully understood, COPD and most likely also other lung diseases seem, per se, to be associated with some sort of cardiac exercise limitation.
The rationale for the use of these biomarkers was twofold: first, each of the novel biomarkers quantifies a distinct and important pathophysiological process or regulatory mechanism known to be of prognostic value in various diseases including HF. Second, these biomarkers have excellent preanalytical and analytical properties as they are inactive and stable fragments of precursor peptides of and thus surrogates for key hormones, which are upregulated in HF and either promote adverse effects by fluid retention and vasoconstriction or, similarly to Btype natriuretic peptide, reflect an insufficient counterregulatory release of hormones with natriuretic and vasodilator properties [39]. Biomarker concentrations were measured from stored samples, and the stability at $-80^{\circ}$ during one 1 year has not formally been shown for all of these peptides. However, available data suggest excellent stability during 6-12 months for MR-proANP, MRproADM, and CT-proET-1. Data on the stability of copeptin during long-term storage are not available. We acknowledge that despite excellent stability at room temperature during 2 weeks [31], some uncertainty persists.

Only approximately $24-29 \%$ of the variability of body weight-indexed peak $\mathrm{VO}_{2}$ was explained by biomarkers, clearly indicating that the isolated use of these biomarkers is not accurate enough to predict peak $\mathrm{VO}_{2}$. However, the purpose of this study was not to propose replacement of CPET by biomarkers but to characterize their associations with pathophysiology. We demonstrated that biomarkers provide information on the response to exercise beyond the set of tests typically included in the armamentarium of the respiratory physician, i.e. measures of lung function. We used different statistical approaches and performed subgroup analyses, and this observation was consistent. The inverse association between peak $\mathrm{VO}_{2}$ and biomarker concentrations was similar in patients with an obstructive and non-obstructive pathology, indicating that these markers may be of value in a large spectrum of lung disease. Given the relative paucity of simple biomarkers in the prognostic assessment of patients with chronic lung disease, our result may be the basis for future studies on the prognostic value of MR-proANP, MRproADM and CT-proET-1 in this setting.

We did not perform a detailed echocardiographic evaluation, which is a limitation of our study. Thus, the link between biomarkers and the exercise response remains speculative. It is, however, possible that similarly to NT-proBNP [33], raised MR-proANP, MR-proADM, and CT-proET- 1 concentrations identify patients requiring an echocardiogram not only to look for LVEF but also for left-ventricular diastolic dysfunction and valvular 
heart disease. It is also possible that raised biomarkers reflect the severity of the pulmonary-cardiac interaction as discussed above which is, however, difficult to quantify. Noninvasive measurement of pulmonary pressures by echocardiography at rest is problematic because on the one hand it is technically challenging in patients with advanced lung disease [40], and on the other hand it does not predict the exercise response.

According to the Fick equation, peak $\mathrm{VO}_{2}$ and oxygen pulse are not only determined by cardiac output and stroke volume, respectively, but also by peripheral oxygen extraction. We acknowledge that we did not assess the physical activity level and skeletal muscle mass and morphology ('the periphery'), which is another limitation of the study. Muscle atrophy and dysfunction is a common feature in patients with advanced COPD and has significant impact on exercise tolerance [41]. It remains unknown whether the biomarkers in our study are related to measures of muscle mass und function. In hemodialysis patients, MR-proADM and C-reactive protein have both been shown to be related to measures of cardiac function and thus to systemic inflammation [42]. It is possible that via a link with systemic inflammation muscle wasting has also contributed to the association between the biomarkers evaluated in this study and peak $\mathrm{VO}_{2}$. A relationship between raised C-reactive protein and raised NT-proBNP in patients with lung disease has been shown previously [43]. Our study has a number of limitations as discussed above. In addition, we studied a small and heterogeneous population. Differences in levels of inflammatory cytokines in this patient group might have had an effect on muscular contractile function and mitochondrial potential. However, we have tried to show that our findings apply for patients with different pulmonary pathophysiology. Second, this is a cross-sectional study design, which fails to provide a causal relation between factors.

\section{Conclusions}

In patients with lung disease, MR-proANP, MRproADM, and CT-proET-1 are inversely associated with peak $\mathrm{VO}_{2}$, and this occurs independent of lung function and oxygenation. These results may be the basis for future studies on the nature of the link between peak $\mathrm{VO}_{2}$ and these markers and their prognostic value in patients with chronic lung disease.

\section{Conflict of Interest}

A.B. and N.G.M. are employees of BRAHMS AG, which is affiliated with Thermo Fischer Scientific, the manufacturer of the tested markers.

\section{References}

1 Ferrazza AM, Martolini D, Valli G, Palange P: Cardiopulmonary exercise testing in the functional and prognostic evaluation of patients with pulmonary diseases. Respiration 2009;77:3-17.

2 Palange P, Ward SA, Carlsen KH, Casaburi R, Gallagher CG, Gosselink R, O’Donnell DE, Puente-Maestu L, Schols AM, Singh S, Whipp BJ: Recommendations on the use of exercise testing in clinical practice. Eur Respir J 2007;29:185-209.

- 3 ATS/ACCP Statement on cardiopulmonary exercise testing. Am J Respir Crit Care Med 2003;167:211-277.

-4 Maeder MT, Brutsche MH, Christ A, Reichlin T, Staub D, Noveanu M, Breidthardt T, Potocki M, Mueller C: Natriuretic peptides for the prediction of severely impaired peak $\mathrm{VO}_{2}$ in patients with lung disease. Respir Med 2009;103:1337-1345.
5 Colice GL, Shafazand S, Griffin JP, Keenan $\mathrm{R}$, Bolliger CT: Physiologic evaluation of the patient with lung cancer being considered for resectional surgery: ACCP evidencebased clinical practice guidelines, ed 2 . Chest 2007;132:161S-177S.

-6 Benzo R, Kelley GA, Recchi L, Hofman A, Sciurba F: Complications of lung resection and exercise capacity: a meta-analysis. Respir Med 2007;101:1790-1797.

7 Benzo RP, Sciurba FC: Oxygen consumption, shuttle walking test and the evaluation of lung resection. Respiration 2010;80: $19-23$.

-8 Barr RG, Bluemke DA, Ahmed FS, Carr JJ, Enright PL, Hoffman EA, Jiang R, Kawut SM, Kronmal RA, Lima JA, Shahar E, Smith LJ, Watson KE: Percent emphysema, airflow obstruction, and impaired left ventricular filling. N Engl J Med 2010;362:217-227.

$\checkmark 9$ Vassaux C, Torre-Bouscoulet L, Zeineldine S, Cortopassi F, Paz-Diaz H, Celli BR, PintoPlata VM: Effects of hyperinflation on the oxygen pulse as a marker of cardiac performance in COPD. Eur Respir J 2008;32:12751282.
10 Khan SQ, Dhillon O, Kelly D, Squire IB, Struck J, Quinn P, Morgenthaler NG, Bergmann A, Davies JE, Ng LL: Plasma N-terminal B-type natriuretic peptide as an indicator of long-term survival after acute myocardial infarction: comparison with plasma midregional pro-atrial natriuretic peptide: the LAMP (Leicester Acute Myocardial Infarction Peptide) study. J Am Coll Cardiol 2008; 51:1857-1864.

11 von Haehling S, Jankowska EA, Morgenthaler NG, Vassanelli C, Zanolla L, Rozentryt P, Filippatos GS, Doehner W, Koehler F, Papassotiriou J, Kremastinos DT, Banasiak W, Struck J, Ponikowski P, Bergmann A, Anker $\mathrm{SD}$ : Comparison of midregional pro-atrial natriuretic peptide with $\mathrm{N}$-terminal pro-Btype natriuretic peptide in predicting survival in patients with chronic heart failure. J Am Coll Cardiol 2007;50:1973-1980. 
-12 Moertl D, Berger R, Struck J, Gleiss A, Hammer A, Morgenthaler NG, Bergmann A, Huelsmann M, Pacher R: Comparison of midregional pro-atrial and B-type natriuretic peptides in chronic heart failure: influencing factors, detection of left ventricular systolic dysfunction, and prediction of death. J Am Coll Cardiol 2009;53:1783-1790.

-13 Khan SQ, O’Brien RJ, Struck J, Quinn P, Morgenthaler N, Squire I, Davies J, Bergmann A, Ng LL: Prognostic value of midregional pro-adrenomedullin in patients with acute myocardial infarction: the LAMP (Leicester Acute Myocardial Infarction Peptide) study. J Am Coll Cardiol 2007;49:15251532.

-14 Khan SQ, Dhillon O, Struck J, Quinn P, Morgenthaler NG, Squire IB, Davies JE, Bergmann A, Ng LL: C-terminal pro-endothelin-1 offers additional prognostic information in patients after acute myocardial infarction: Leicester Acute Myocardial Infarction Peptide (LAMP) Study. Am Heart J 2007; 154:736-742.

15 Neuhold S, Huelsmann M, Strunk G, Stoiser B, Struck J, Morgenthaler NG, Bergmann A, Moertl D, Berger R, Pacher R: Comparison of copeptin, B-type natriuretic peptide, and amino-terminal pro-B-type natriuretic peptide in patients with chronic heart failure: prediction of death at different stages of the disease. J Am Coll Cardiol 2008;52:266-272.

16 Khan SQ, Dhillon OS, O’Brien RJ, Struck J, Quinn PA, Morgenthaler NG, Squire IB, Davies JE, Bergmann A, Ng LL: C-terminal provasopressin (copeptin) as a novel and prognostic marker in acute myocardial infarction: Leicester Acute Myocardial Infarction Peptide (LAMP) study. Circulation 2007;115: 2103-2110.

17 Maeder MT, Brutsche MH, Christ A, Staub D, Noveanu M, Breidthardt T, Schaub N, Potocki M, Reichlin T, Morgenthaler NG, Bergmann A, Mueller C: Midregional pro-A-type natriuretic peptide for the evaluation of exercise intolerance. Int J Cardiol 2009, Dec 22. Epub ahead of print.

-18 Jougasaki M, Rodeheffer RJ, Redfield MM, Yamamoto K, Wei CM, McKinley LJ, Burnett JC, Jr: Cardiac secretion of adrenomedullin in human heart failure. J Clin Invest 1996;97:2370-2376.

19 Pousset F, Masson F, Chavirovskaia O, Isnard R, Carayon A, Golmard JL, Lechat P, Thomas D, Komajda M: Plasma adrenomedullin, a new independent predictor of prognosis in patients with chronic heart failure. Eur Heart J 2000;21:1009-1014.

20 Haynes WG, Strachan FE, Webb DJ: Endothelin ETA and ETB receptors cause vasoconstriction of human resistance and capacitance vessels in vivo. Circulation 1995;92: 357-363.
21 Allen SW, Chatfield BA, Koppenhafer SA, Schaffer MS, Wolfe RR, Abman SH: Circulating immunoreactive endothelin-1 in children with pulmonary hypertension. Association with acute hypoxic pulmonary vasoreactivity. Am Rev Respir Dis 1993;148: 519-522.

-22 Morgenthaler NG, Struck J, Jochberger S, Dunser MW: Copeptin: clinical use of a new biomarker. Trends Endocrinol Metab 2008; 19:43-49.

23 Kelly D, Squire IB, Khan SQ, Quinn P, Struck J, Morgenthaler NG, Davies JE, Ng LL: C-terminal provasopressin (copeptin) is associated with left ventricular dysfunction, remodeling, and clinical heart failure in survivors of myocardial infarction. J Card Fail 2008; 14:739-745.

24 Maeder MT, Brutsche MH, Staub D, Morgenthaler NG, Bergmann A, Noveanu $\mathrm{M}$, Laule K, Breidthardt T, Christ A, Klima T, Reichlin T, Potocki M, Mueller C: B-type natriuretic peptide and C-terminal-pro-endothelin-1 for the prediction of severely impaired peak oxygen consumption. J Intern Med 2009;265:604-615.

25 Gibbons RJ, Balady GJ, Bricker JT, Chaitman BR, Fletcher GF, Froelicher VF, Mark DB, McCallister BD, Mooss AN, O’Reilly MG, Winters WL, Gibbons RJ, Antman EM, Alpert JS, Faxon DP, Fuster V, Gregoratos G, Hiratzka LF, Jacobs AK, Russell RO, Smith SC: ACC/AHA 2002 guideline update for exercise testing: summary article. A report of the American College of Cardiology/American Heart Association Task Force on Practice Guidelines (Committee to Update the 1997 Exercise Testing Guidelines). J Am Coll Cardiol 2002;40:1531-1540.

26 Robbins M, Francis G, Pashkow FJ, Snader CE, Hoercher K, Young JB, Lauer MS: Ventilatory and heart rate responses to exercise: better predictors of heart failure mortality than peak oxygen consumption. Circulation 1999;100:2411-2417.

-27 Schmid A, Schilter D, Fengels I, Chhajed PN, Strobel W, Tamm M, Brutsche MH: Design and validation of an interpretative strategy for cardiopulmonary exercise tests. Respirology 2007;12:916-923.

-28 Morgenthaler NG, Struck J, Thomas B, Bergmann A: Immunoluminometric assay for the midregion of pro-atrial natriuretic peptide in human plasma. Clin Chem 2004;50: 234-236.

29 Morgenthaler NG, Struck J, Alonso C, Bergmann A: Measurement of midregional proadrenomedullin in plasma with an immunoluminometric assay. Clin Chem 2005;51: 1823-1829.

30 Papassotiriou J, Morgenthaler NG, Struck J, Alonso C, Bergmann A: Immunoluminometric assay for measurement of the C-terminal endothelin-1 precursor fragment in human plasma. Clin Chem 2006;52:11441151 .
31 Morgenthaler NG, Struck J, Alonso C, Bergmann A: Assay for the measurement of copeptin, a stable peptide derived from the precursor of vasopressin. Clin Chem 2006;52: 112-119.

32 DeLong ER, DeLong DM, Clarke-Pearson DL: Comparing the areas under two or more correlated receiver operating characteristic curves: a nonparametric approach. Biometrics 1988;44:837-845.

$\checkmark 33$ Wieshammer S, Dreyhaupt J, Basler B, Marsovszky E: NT-proBNP for pulmonologists: not only a rule-out test for systolic heart failure but also a global marker of heart disease. Respiration 2009;77:370-380.

34 Socrates T, Muller C: Natriuretic peptides find a new home in pulmonology. Respiration 2009;77:368-369.

35 Kinugawa T, Kato M, Ogino K, Osaki S, Igawa O, Hisatome I, Shigemasa C: Plasma endothelin-1 levels and clinical correlates in patients with chronic heart failure. J Card Fail 2003;9:318-324.

>36 Jorgensen K, Muller MF, Nel J, Upton RN, Houltz E, Ricksten SE: Reduced intrathoracic blood volume and left and right ventricular dimensions in patients with severe emphysema: an MRI study. Chest 2007;131: 1050-1057.

37 Holverda S, Rietema H, Westerhof N, Marcus JT, Gan CT, Postmus PE, Vonk-Noordegraaf A: Stroke volume increase to exercise in chronic obstructive pulmonary disease is limited by increased pulmonary artery pressure. Heart 2009;95:137-141.

- 38 Vonk Noordegraaf A, Marcus JT, Roseboom B, Postmus PE, Faes TJ, de Vries PM: The effect of right ventricular hypertrophy on left ventricular ejection fraction in pulmonary emphysema. Chest 1997;112:640-645.

39 Schrier RW, Abraham WT: Hormones and hemodynamics in heart failure. $\mathrm{N}$ Engl J Med 1999;341:577-585.

40 Arcasoy SM, Christie JD, Ferrari VA, Sutton MS, Zisman DA, Blumenthal NP, Pochettino A, Kotloff RM: Echocardiographic assessment of pulmonary hypertension in patients with advanced lung disease. Am J Respir Crit Care Med 2003;167:735-740.

41 Schols AM, Gosker HR: The pathophysiology of cachexia in chronic obstructive pulmonary disease. Curr Opin Support Palliat Care 2009;3:282-287.

-42 Yoshihara F, Ernst A, Morgenthaler NG, Horio T, Nakamura S, Nakahama H, Nakata H, Bergmann A, Kangawa K, Kawano Y: Midregional proadrenomedullin reflects cardiac dysfunction in haemodialysis patients with cardiovascular disease. Nephrol Dial Transplant 2007;22:2263-2268.

43 Wieshammer S, Dreyhaupt J, Basler B: A link between impaired lung function and increased cardiac stress. Respiration 2010;79: 355-362. 